\title{
Coupling Research on Governing Structure and Enterprise Technology Innovation
}

\author{
Lei Zhan ${ }^{1, a^{*}}$ and Lu Yu, b \\ ${ }^{1}$ School of economics, Sichuan University, Chengdu, Sichuan Province ,China \\ a2399449632@qq.com, b488897525@qq.com
}

Keywords: Governing Structure; Equity Mechanism; Technology Innovation

\begin{abstract}
The fact that governing structure is an important factor to affect enterprise technology innovation was explained through relation analysis from three aspects of company governing structure including equity mechanism, mechanism of creditor's right and board structure on technology innovation in this thesis. Policy measures in many aspects such as changing enterprise equity mechanism, increasing holing ratio of operator, increasing long-term loan ratio and improving director system, etc were proposed through detailed theoretical analysis in this thesis, thus enterprise technology innovation was accelerated through improving governing structure.
\end{abstract}

\section{Introduction}

Global economic integration has intensified and technology development and innovation has been accelerated with the advent of $21^{\text {st }}$ century. As enterprises with technology innovation as main body, competition focus is transformed from products to technology competition based on knowledge in external environment of changing market competition pattern. Enterprises become main body of technology innovation and competition result among enterprises is finally decided by innovation state of enterprises. Competition among enterprises is more and more intensified in the overall environment of competition of "internationalization of domestic market" and "nationalization of international market", and adverse status of enterprises in competition and even perdition of enterprises can be caused due to insufficient input of technology innovation or decision-making deviation of technology deviation possibly. So, it is the key to establish effective power mechanism and decision-making mechanism of technology innovation for enterprises to ensure input enthusiasm of technology innovation and decision-making correctness of technology innovation. Effective technology innovation mechanism is established based on arrangement of company governing structure, or it can be said that technology innovation mechanism of enterprises is subject to company governing frame[1]. So, reasonable company governing policy is formulated to accelerated improvement of technology innovation mechanism of enterprises through analyzing relation between governing structure and enterprise technology innovation in this thesis.

\section{General Summary of Relation between Governing Structure and Technology Innovation}

Attention of governing structure in western economic circle can be dated back to Adam Smith (1776) and Berle and Means (1932) clearly put forward the opinion of "separation of ownership and control power" for the first time in the book named Modern Company and Private Property, and it was stated that separation of the two powers would surely lead to the problem of company governing structure[2]. Domestic scholars have different definitions on governing structure in different angles for the conception of company governing structure. Wu Jinglian thought that company governing structure referred to a kind of organization structure composed of owners, Board of Directors and senior managers; Qian Yingyi thought that company governing structure was an overall set of system arrangement to handle relation among different stakeholders including shareholder, borrower, management personnel and employee to realize economic goal; Zhang Weiying thought that company governing structure referred to system arrangement in aspects of function, structure of Board of Directors of company and shareholder's power, etc in narrow sense, and it referred to an overall set of legal, cultural and systematic arrangement on allocation of control power and residual claim of company in broad sense. So, definition adopted in this 
thesis is that company governing structure is a kind of system to coordinate mutual relation between shareholders and other stakeholders in reference to opinions of scholars at home and abroad.

So, does company governing structure affect enterprise technology innovation? Hoffman and Hegarty (1993) pointed out that enterprise governing structure affects technology innovation activity through affecting innovation attitude of operators. Among many factors affecting enterprise technology innovation, strong support of the highest management (namely operator) on technology is the most important factor (Nakahara, 1997). Scholars such as Zahra, etc (2000) found that shareholding ratio of enterprise manager is of significant positive relation to enterprise technology innovation activity through empirical research of innovation activity for medium-sized enterprises. Besides, Chinese scholars Yang Jianjun and Li Yuan (2002), etc described behavior feature of technology innovation for entrepreneurs with four variables such as innovation impetus, innovation ability, innovation power and innovation decision-making and constructed comprehensive model on mutual relation of four variables. Their analysis indicates that innovative decision-making of entrepreneurs is their important behavior feature and innovative decision-making is comprehensive reflection of innovative impetus, innovative ability and innovative power. Exertion of innovative ability is affected by innovative impetus and power and innovative impetus and innovative power of entrepreneurs are decided by internal and external governing mechanism which can be used by Board of Directors to a great extent.[3]

We can found through above theories that economists mainly analyze influence of technology innovation pertinent to a certain aspect of company governing structure, while there is no comprehensive elaboration on function of technology innovation in terms of integrity of governing structure, so influence of technology innovation is analyzed in several aspects of company governing structure in this thesis, and construction of Chinese enterprise governing structure is proposed on this basis to realize mutual coupling of technology innovation and governing structure of enterprises.

\section{Influence of Governing Structure on Technology Innovation}

Equity Structure and Technology Innovation. Problem of enterprise governing structure appears with agency risk of separation of two rights to further affect impetus and decision-making of technology innovation of enterprises. Entrustment-agent system is irreversible product of social division of labor in one aspect to greatly accelerate increase of enterprise operation efficiency, and it causes problems such as interest of major and minor shareholders is inconsistent and interest of shareholders and operators is incompatible, etc to lead to contradictions in aspect of decision-making selection[4].

First, there is incompatible situation of interest between owners and operators, for owners pursue maximization of enterprise profit and long-term profit, so they prefer selecting technology innovation behavior which can bring long-term effect to enterprises. However, as main body of technology innovation, enterprise operators consider recent goal of enterprises to reach assessment requirement of shareholders on them more, then the enterprises will be in adverse status in competition for operators will give up technology innovation and select relative conservative operation behavior due to the fact that there is relatively great risk of technology innovation and delay phenomenon of profit. So, enterprise operators will not conduct technology innovation in efforts for long-term interest of enterprises possibly if there are no effective incentive measures on operators for enterprises. Effective incentive measures will keep interest of owners and operators consistent and make them pay attention to long-term goals of enterprises to select technology innovation means commonly, so reasonable share incentive mechanism is an effective way to accelerate enterprise technology innovation.

Secondly, value orientation of controlling shareholder and minority shareholders is different in terms of shareholder structure, so different shareholders may pursue different goals. As actual owner of the enterprise, controlling shareholder aims to finance to the greatest degree to accelerate long-term and stable development of the company and finally withdraw asset cost and obtain surplus. Minority shareholders aim to be opportunistic and they do not care about long-term development of the company. Controlling shareholder cares more about motivation and monitoring of enterprise technology innovation than minority shareholders for technology innovation involves long-term development of the company and establishment of competitiveness. However, minority shareholders care more about appreciation of 
input capital in premise of safety and profit motivation of technology innovation is not obvious for share ratio of minority shareholders is not high, while huge loss may be caused to minority shareholders if innovation fails, so minority shareholders of low share ratio are not willing to select technology innovation behavior of great risk.

Claim Structure and Technology Innovation. Technology innovation of enterprises needs sufficient capital support and loan is one of the main ways for enterprises to obtain cash flow. Influence of loan on governing structure of enterprises is mainly presented in two aspects of motivation and transferring of controlling right. In one aspect, enterprises pay interest with pretax income to act as tax saving. Meanwhile, return on equity also increases correspondingly and this kind of increasing effect of debt on enterprise profit will surely increase profit of operators to motivate them to work harder with increase of enterprise debt amount on condition that profit margin is over debt interest rate[4]. In the other aspect, debt financing is a kind of hard constraint on enterprises and it is reflected in the fact that enterprises shall pay per periods according to contract agreement if debt is due and enterprises will have the risk of bankruptcy if the debt cannot be repaid on schedule. Reputation of operators of bankrupt enterprises will be greatly damaged and their human capital will be devalued so that it will be very hard for them to find satisfactory work in the future. Reputation of enterprises will greatly be lowered and financing opportunity in the future will be reduced and cost will be increased if interest cannot be paid on schedule and operation difficulty of enterprises and possibility of managers to be unemployed will both increase in this circumstance. As main body of technology innovation, enterprise operators shall consider risk and profit matching and operators may give up innovative behavior to ensure that debt can be promptly be repaid in face of innovative failure and market risk for it needs long periods to present profit caused by innovation. Meanwhile, enterprises with high debt-to-assets ratio will be subject to strict management of creditor on capital investment of enterprises and it is because use of most cash for enterprises is restricted by debt contract, and investment in the aspect of enterprise technology innovation is normally exclusive asset not easy to be reused. So, technological innovative behavior of enterprises may be in negative relation to debt level of enterprises.

Liability of enterprises can be divided into short-term liability and long-term liability through further analysis. Short-term liability makes operators face short-term profit pressure and high input of technology innovation will reduce profit for the term. Long-term profit of technology innovation makes enterprises face pressure of not being able to repay short-term liability, thus it causes threatening to stability of position for operators and operators will have no enthusiasm to be engaged in technology innovation activity. However, enterprises need to be equipped with ability of long-term profit with increase of long-term liability and technological advancement can increase core competitiveness of enterprises, increase competitiveness of enterprises and long-term profitability. It can be found from this that technological innovation of enterprises is in negative relation to short-term liability and positive relation to long-term liability.

Structure of Board of Directors and Technological Innovation. Board of Directors in new-type enterprise models will gradually substitute main controlling right of General Manager on operation an decision-making in enterprises in planned economic system, so it is very important to research influence of structure of Board of Directors in incorporated enterprises on technological innovation. Leadership structure and Independent Directors have great influence on work efficiency of Board of Directors to further affect technological innovative behavior of enterprises. Leadership structure refers to organizational structure of integration or separation of Chairman and General Manager.

It is thought in enterprise governing theory that enterprise leadership structure (integration or separation of Chairman and General Manager) will affect enterprise technology innovation and the reason is that enterprise leadership structure will affect independency of Board of Directors of enterprises and innovation of execution layer of managers. It has been analyzed at the time of stating equity structure and technology innovation hereinbefore that technology innovation activities have the features of high input, high return and high risk. Shareholders pursue long-term value of enterprises and maximization of investment profit and high return caused by high risk wholly compared with operators, so they tend to select technology innovation behavior. As the representative of shareholders, Board of Directors has the 
same value orientation as shareholders and they also pursue long-term profit maximization of enterprises and support enterprise technology innovation. However, operators will avoid technology innovation to avoid risk and ensure stability of enterprise operation in their tenure. Then the problem that goals of shareholders and operators of the enterprise are different occurs. Integration of Chairman and General Manager will then reduce confliction to ensure consistency in the aspect of selection and decision-making of technology innovation. Meanwhile, integration of the two posts can give more innovative autonomy for managers restrained by risk consciousness so that they will consider and take charge of formulation and implementation of strategic planning of enterprise technology innovation more actively to realize self-value of managers. Possibility of integrating two posts will be greater and driving force of technological innovation selection will be stronger to increase innovative behavior of enterprises if shareholding ratio of enterprise operators is higher. So, integration of Chairman and General Manager is in positive relation to technology innovation. However, it is thought in theoretical analysis of separation of two rights that Chairman and managers shall be occupied by different people for integration of Chairman and General Manager will also lead to adverse influences such as reduce of enterprise operation efficiency, etc.[5]

The fundamental aim of establishing Independent Directors is to prevent holding shareholders, management shareholders and major shareholders from damaging interest of other shareholders, especially minority shareholders and public shareholders. Does setting of independent shareholders accelerate technology innovation? Influences of Independent Directors to enter into Board of Directors and participate in company governing on technology innovation are as follows: technology innovation can be boosted for Independent Directors to join in Board of Directors of company. Independent Directors are commonly professional personnel in certain fields, especially in enterprises predominant in technology innovation, so they can use their professional knowledge and experience to offer constructional suggestions for company development and decision-making of Board of Directors and help the company to formulate reasonable technology innovation strategy with their advantages of information and knowledge. Secondly, Independent Directors are focused on overall development of enterprise and interest of all stakeholders at the time of conducting strategic decision-making in perspective of fundamental aim of establishing Independent Directors, so they shall consider long-term aim of enterprises and stable development of enterprises at the same time. It is good for enterprises to develop their own special technological ability and accumulate self-owned technology talents of enterprises continuously through technology innovation. So, establishment of Independent Directors has great benefit on technology innovation of enterprise.

\section{Conclusion and Suggestion}

It can be found from above theoretical analysis that company governing structure is closely related to enterprise technology innovation and enterprise governing structure shall be adjusted so that it can conform to need of technology innovation development to better promote technological innovative behavior of enterprises and to make enterprises in an advantageous position in market of fierce competition.

Change of Equity Structure. It is kernel of enterprise governing structure for owners to invest on enterprises freely with their assets to pursue maximization of investment profit and undertake the risk caused by this and allocate enterprise controlling right and operation right in principle of "separation-balance" according to contribution ratio in current market economy. Degree of concentration and dissipation of equity will directly affect impetus and decision-making selection of enterprise technology innovation, so an enterprise mainly on technology innovation shall consider equity allocation of enterprise including ratio of major, medium and minority shareholders and equity motivation on operators so that equity allocation will act as the role of motivating enterprise technology innovation.

Meanwhile, innovative autonomy shall be given to operators to strengthen motivation and restraint on them. Interest of operators and shareholders can be kept consistent to guarantee that operators always offer powerful support to enterprise technology innovation through increasing holding ratio of enterprise operators. Equity motivation system uniforms operator aim and long-term value aim of the company so 
that it can be an entirety with enterprise to undertake interests and risks to realize restraint and motivation on operators through making operators hold enterprise shares in different ways.

Improvement of Claim Organization. Financial leverage shall be applied as possible to ensure implementation of enterprise innovation behavior pertinent to the feature of high input of technological innovation to obtain stable cash flow to support technological innovation through financing. However, it shall be guaranteed that business profit ratio formed through innovation is higher than indebted interest rate firstly so that it can be ensure that enterprises will obtain profit. Risk of enterprises to conduct technology innovation through liability is further increased in current status that loan interest rate is continuously increased in the nation, so enterprise should firstly reasonably control asset-liability ratio before financing to implement technology innovation. Secondly, long-term liability ratio shall be increased to reduce short-term liability ratio so that liability index can be matched to hysteretic nature of technological innovative effect of enterprises to accelerate needs of enterprise technology innovation when asset-liability ratio is certain.

Improvement of Systems of Board of Directors and Independent Directors. Integration of Chairman and General Manager is in positive relation to technology innovation in perspective of enterprise technology innovation. However, there is obvious negative effect of integration of two rights on operation efficiency of enterprises according to theoretical analysis of separation of two rights. So, integration and separation of two rights of Chairman and managers are not the key affecting technology innovation and essence of the problem is that they share the same goal and achieve proper balance among innovative freedom degree, innovative motivation and effectiveness of operators according to operating condition of enterprises.

Chinese enterprises shall universally increase ratio of Independent Directors in Board of Directors to increase independency of Board of Directors. Independent Director is an effective mechanism to enhance function of independent decision-making of Board of Directors and Chinese enterprises shall establish supporting mechanism of effective operation of independent directors to increase independency and scientific nature of decision-making of Board of Directors.

\section{References}

[1] J.Y.Hua:Discussion on Influence of Company Governing on Enterprise Technology Innovation . Journal of Dialectics of Nature, Vol.(2002) No.1.

[2] F.Wei and X.Liu: Influence of Internal Mechanism on Enterprise Technology Innovation for State-owned Enterprises. Journal of Chongqing University, Vol.(2004) No.3.

[3] J.J.Yang, Y.Li and Q.Xue :Feature Analysis of Technological Innovative Behavior of Entrepreneurs based on Company Governing. China Soft Science, Vol.(2000) No.12.

[4] J.F.Xu and Y.Liu: Enterprise Governing Structure and Technological Innovation. Scientific Research Management, Vol.(2002) No.4.

[5] L.Chen, Z.Y.Zhang and X.S.Yang. Influence of Company Governing Structure of Listed Enterprises on Technological Innovation. Scientific Management Research, Vol.(2005) No.9. 